\title{
The Challenge of Research Supervision: The Experience of Lecturers in Various Academic Disciplines
}

\author{
Angela Wright \\ Department of OPD, Cork Institute of Technology, Cork. Rep. of Ireland.
}

\begin{abstract}
Research supervision is the highest level of teaching for academics. Yet, in many cases, academics are allocated supervision without any formal training. For many supervisors, their supervision approach will be a mirror of what they have experienced themselves at post-graduate levels. Many supervisors consider that this form of teaching is stressful and onerous due to the responsibility placed on it by the Higher Education Institution and the student ultimately. What can be done to support supervisors in their supervisory journey? There is a void in the academic literature on research supervision with scant aids available to the supervisor (Cullen, 2009). Brew and Boud (1995) outline the importance of instructor knowledge; however, supervisors only gain extensive supervisory experience over the years.

The aim of this study is to better understand the supervisory process. Data was gathered from 12 lecturers engaged in supervision across various disciplines.

Findings indicate that supervisors need to adopt and continually change to differing circumstances and different student personalities while supervising. It is essential that formal supervisory training be provided for all supervisors. The findings from this evaluation are novel and will be beneficial to research supervisors across various disciplines.
\end{abstract}

Keywords: Research Supervision; Multi-Disciplinary; Reflection. 


\section{Introduction}

Quality supervision in teaching and learning in Higher Education has several challenges. For many, a fundamental understanding of 'what research actually is' is important. How do the student and research supervisor view the research process? When a supervisor meets a student for their first supervisory meeting, they are anxious as to the expectations of the student and, of course, the standard that the student already has in terms of skills, knowledge and experience. Many conflicts exist for example, the fundamental understanding of 'what is research'? What does the student think it will involve? How is research perceived in today's context and in everyday life? Research can mean different things to different students, some, for example, are only aware of research in relation to political polls at election time, others relate to research in relation to nutrition and health and medical research; scientists looking for cancer cures. When it comes to their own personal research in the context of Business, Humanities or Science, how do they perceive this journey, and how does the academic supervisor set the expectations for the journey ahead? The context of this paper is to examine the journey from an academic supervisory perspective in cross-sectoral discipline areas in an Irish Institute of Technology. The participants in this study are all from varying faculties where they supervise students from undergraduate projects, to post-graduate taught and full research thesis, to $\mathrm{PhD}$. The intention of this research is specifically to broaden the author's own personal teaching horizons, particularly the current research supervision practices and approaches in place, to gain insights to improve supervision practice. Research supervision places one at the epicentre of new and exciting empirical data, while equally placing an immense challenge and responsibility on the supervisor, namely, the successful graduation of students under one's supervisory care. This research addresses a dearth in the academic literature (Delany, 2009), specifically in relation to understanding research supervision.

\section{Aims \& Objectives of this Research}

The overarching aim of this research is to examine and understand the fears and expectations of lecturers when they begin their supervisory journey. The main objective of this research is to gain an insight into the issues in relation to supervision, to inform practice, and to move forward in a supervisory capacity with more appropriate informed thinking. Another objective is to develop new processes to facilitate future supervisory student engagement.

\section{Methodology}

A post-positivistic approach was applied to gather the empirical data. Therefore, for the purposes of this research study, face to face discussions using a semi-structured interview guide (pilot tested to ensure reliability and validity) were held with research supervisors in a Higher Educational setting to ascertain how they viewed research supervision. Twelve lecturers (9 
females, 3 males) took part in the study across multiple disciplinary areas from science to humanities. The criteria to be included in the sample comprised of being current full-time lecturers, and participation in research supervision, be it at undergraduate fourth year project, or PhD level. The data was analysed using grounded theory (Strauss \& Corbin, 1998) and the themes that emerged are outlined below. All lecturers remained anonymous, and all ethical procedures were ensured and adhered to.

\section{Literature}

The student and the supervisory relationship are inextricably linked (Armstrong, 2004). The relationship can change throughout the period for various reasons. This is mainly due to the style of the supervision (Visser- Wijnveen et al., 2010). Student and lecturer expectations are often mismatched for various reasons causing anxiety for the student \& supervisor (Sorcinelli, 2007). The roles and functions of research supervision are multiple, for students, the ideal supervision helps them to achieve a scientific result, or achieve a personal goal, learn about the research processes, but, specifically, how to conduct research critically and at the right standard (Visser- Wijnveen et al., 2010; Zhao, 2001). Higher education is tasked with engaging students in questioning their preconceived ideas and their models of how the world works, so that they can reach a higher level of understanding (McAleese, 2013). Lack of respectful relationships between students and faculty members are also a concern (Ghadirian et al., 2014), together with ensuring that quality standards at supervisory level of education, training and research are assured (Baptista, 2011).

\subsection{Supervisory Styles}

Research supervision is the most advanced level of teaching (Zhao, 2001) and is a process of fostering and enhancing learning, research and communication at the highest level in the educational system. The student/lecturer relationships are intricate, and advice is needed (Cullen, 2009); however, the advisory literature available to academics is scant, and hence, many supervisors have a dearth of literature from which to draw (Delany, 2009). It is advisable that the academic community endeavour to bridge the gap and inform practice (Cullen, 2009). In the view of students, optimal supervision helps them to achieve the result, and acquire same within the institutional research standards and processes (Zhao, 2001). Concerns facing the supervisory voyage is managing the overall process and levels of expectations (Sorcinelli, 2007; Visser- Wijnveen et al., 2010). The fact remains that teaching and learning in higher education is a shared process, with responsibilities on both the student and lecturer to contribute to their success and enable the research journey (McAleese, 2013). In the UK, for example, The Good Supervisory Practice Framework, acknowledges, for the first time, the wide-ranging, highly complex and demanding set of roles involved in research supervision, such as recruitment and selection, supervisory relationships with candidates and 
with co-supervisors, supporting candidates' research projects, encouraging candidates to write, giving appropriate feedback, keeping the research on track and monitoring progress, supporting candidates' personal and career development, supporting candidates through completion and final examination, supporting candidates to disseminate their research, and to reflect on practice (supervision.ukcge.ac.uk).

\subsection{Approaches to Research Supervision}

In terms of research supervision, various approaches exist (Gatfield, 2005; Lee, 2007), where both offer four approaches to research supervision. Gatfield (2005) presents a model using four main supervisory styles. The four elements proposed by Gatfield are: Pastoral Carelow structure and high support; Contractual Style — high structure and high support, Laissez Faire-low structure low support; and Directorial Style - high structure and low support (researchsuper.chelt.anu.edu.au). Lee (2007) also proposes four models of supervision: Functional (a structured approach), Critical Thinking, Enculturation \& Mentoring (the mentor provides all the support but allows the student space to breath, but problems may arise with responsibility). Great care is needed when applying the mentoring approach (Lee, 2007). Conversely, Zhao (2001) outlined the preferred process of strict research plans, encouraging good planning over 'ad hoc' processes.

\section{Main Findings \& Discussion}

The following section outlines some of the pertinent findings from this research study. Only key themes are presented due to the limitations of the paper. Many other themes and subthemes emerged, but are not included in the scope of this paper.

\subsection{An Understanding of the Research Process}

Students embarking on the research journey do not realise what is involved. When it came to forth year research projects, supervisors $(85 \%)$ believe that students do not understand what is involved and view a research project like "any other subject". There are various levels in the process, and the understanding of the research process for a fourth year project and a Level 10 research process are "worlds apart". The main challenge for me, as a supervisor, is to "understand what my students need moving from degree level supervision to even masters level, not to mention the challenges for students going directly onto the $\mathrm{PhD}$ register from degree level". "Other comments from participants included, "students do not understand what format the research journey will take for them".

\subsection{Understanding One's Approach to Supervision}

Most supervisors had never considered what their actual approach to supervision was. $70 \%$ stated that when they embarked on the research supervision, they apply a more functional 
and instructional approach (Lee, 2007), and when the student has grasped some of the research techniques, they "think" that they become mentors". "Mentoring allows the research student find their own way and breath". "It is important for the student to find their own personal research journey, particularly, and especially, if they want to go on to PhD level". Participants outlined that there are some cases where the students need a more "hands on" direction, and struggle with "self-directed learning"; this is challenging. Other participants from the discussion considered that they actually used "a combination of styles depending on the student ability". One supervisor from the discussions, relayed that, when they started supervising first, they "were more scared" that the student, as there was no available training in supervision for lecturers. The supervisor/student relationship is a very different one, and can be complicated. "Maintaining parameters can be a challenge, and not becoming too personally involved". $90 \%$ of participants are concerned about managing the relationship, and afraid of getting too "entangled" with students. It is also important to be positive. Reflecting Visser- Wijnveen et al., (2010), there are many rewards from research supervision. Participants here stated that showing "students what is exciting about research is vital".

\subsection{Critical Thinking}

Critical thinking is 'key' to all research and the basis of what the research student is trying to achieve. Challenges for research supervisors included trying to get students to think critically. This was particularly evident for early researchers (Visser- Wijnveen et al., 2010), but the anxiety for supervisors was no less as they still had to see the student through the process. "One of the key challenges for me, particularly at fourth year project level, is trying to get the student to be critical". "How do you get students to evaluate a conceptual framework?" "Getting students to engage in a lot of questioning can be interesting". Another supervisor advocated training in terms of both supervisor and student to ease the pressure. "We and the students need training".

\subsection{Adversarial Students}

Participants in this study discussed that students can be challenging and vocal and that it can be difficult to manage the supervisory meeting (85\%). This applied to all disciplines and levels. Some students do not want to take direction and do not understand that the advice is not personal. Students are not fearful of voicing their opinions (Lewis, 2010). Students exercise control over the quality of their learning by "evaluating their teachers' performance" (Sorcinelli, 2007: 2); findings from the supervisors mirror this. Giving student feedback was another concern and "fear" for some supervisors, but Brown (2007) believes that some students fail to consider the feedback in a positive way. "It challenging to give feedback as some students do not take it very well". $80 \%$ of the participants in this study agreed; one stated that they often worry about giving back research work with lots of "mark-ups", as students contest some suggestions strongly. 


\subsection{Reflection to Aid Learning}

In line with Moon (2001), reflection for the research student is an important part of the process. Participants in this study were strong advocates of reflection believing that reflection leads to enhanced learning and deep reflection impacts well on the research process. "More encouraged now as part of the research journey, reflection is vital". "I was delighted that reflection now forms part of course content". "This will make the supervisory process less 'dictatorial"". "Encouraging students to keep a reflective journal that can be reviewed during and after their research journey has been very useful and helpful along the way". "For me, asking the students to keep a reflective journal has helped with the feedback process too".

\subsection{Responsibility}

Students are concerned with results (Race, 1993), to graduate, and this was voiced by participants as a grave concern. Participants outlined that it was an "onerous task to take on supervision, particularly $\mathrm{PhD}$ supervision". The concerns that were outlined are in relation to the responsibility of the Viva Voce (55\%). "There is an expectation to pass when one has gone through the $\mathrm{PhD}$ research process, but I have seen cases where this has not happened, and the supervisor is left with 'egg on their face', and blamed". "It would be much easier for me to just teach regular classes at undergraduate level". "I try not to think of the responsibility".

\section{Recommendations}

Many issues came to the fore in this study in relation to the challenges of research supervision. Some of the main concerns centered on the onerous task. Supervisors stated that they are not given specific training in terms of research supervision. "I have been supervising for years without any specific training". Proper formal training is a strong recommendation of this study, together with continuous review. We must put practice "under the spotlight", (Biggs, 1999:73). Formal 'train the trainer' programmes must be implemented. It is important, therefore, that all faculties give relevant support to lecturers who supervise. Awareness of the issues needs highlighting to other fellow academics within and beyond the faculties where workshops and support groups should be encouraged. It is important that supervisors improve practice (Harvey, 1998), and this can only be achieved through continuous evaluation, reflection and learning. Supervisors must understand the issues to improve personal practice and student learning (Ramsden, 2003; Visser- Wijnveen et al., 2010). All Higher Educational institutions need to support supervisors and provide ongoing training. Collaboration with other Higher Education institutions would be of benefit to see what processes are in place through proven evaluated programmes. Students are not sure what is needed from them when it comes to research projects, therefore more formal class work with supports would be very beneficial, together with clear roadmaps (Gatfield, 2005). To avoid issues in relation to difficulties with structure, work progress, and problematic abandonment of the 
endeavour entirely, formal timetabling of supervision must be factored over 'ad hoc' approaches reported by some supervisors.

\section{Conclusion}

Every supervision is a unique relationship and it is important, as a supervisor, to recognise this dynamic. Research students differ wholly in constitution; each one brings a unique ability and personality to the research process, and capabilities vary enormously. Some students thrive on freedom; others do not, with more needing constant contact, guidance \& support. For the research supervisor, it is vital that one understands what the student is going through in order to have successful outcomes. Supervisors must adapt to the varying situations. Academic outcomes at the higher research level are vitally important as the contributions are the bedrock of progress in each discipline, together with enriching the world about us. No two research situations will ever be the same, but, as a supervisor, how can one ensure consistency in practice and success with our research students? The process has the optimum opportunity of delivering worthwhile results when the best and most applicable path is taken by the students, while supported by a fully prepared and introspective supervisor.

\section{References}

Armstrong, S. (2004). “The Impact of Supervisor's Cognitive Styles on the Quality of Research Supervision”, in Management Education. British Journal of Educational Psychology, Vol. 74, pp. 599-616, http://dx.doi.org/10.1348/0007099042376436 PMid:15530204

Baptista, A. V. (2011). "Challenges to doctoral research and supervision quality: A theoretical approach”, Procedia - Social and Behavioral Sciences, Volume 15, Pages 3576-3581, ISSN 1877-0428, https://doi.org/10.1016/j.sbspro.2011.04.338.

Biggs, J. (1999). "What the student does: teaching for enhanced learning", Higher Education Research and Development, Vol. 18, No. 1, p57-75, available at http://www.tcd.ie/vpcao/academic-development/assets/pdf/Biggs_1999_Teaching_for_enhanced_learning.pdf.

Brew, A, and Boud, D. (1995). "Teaching and Research: Establishing the Vital Link with Learning", Springer, Higher Education, Vol. 29, No. 3, pp. 261-273, available at : http://www.jstor.org/stable/3447715.

Brown, S. (2007). "Feedback and Feed-forward", The Higher Education Academy, Centre for Bioscience bulletin, No. 22, Autumn, ISSN 1740-6706 (Online), available at, http://www.bioscience.heacademy.ac.uk/ftp/newsletters/bulletin22.pdf.

Cullen, S. (2009). "Resource Guide to Dissertation Supervision on Taught Undergraduate and Postgraduate programmes", The Hospitality, Leisure, Sport and Tourism Network, March, Thames Valley University, available at http://www.academia.edu/6935303/Resource_Guide_to_Dissertation_Supervision_on_Taught_Undergraduate_and_Postgraduate_Programmes. 
Delany, D. (2009). “A Review of the Literature on Effective PhD Supervision, Dublin:Trinity College Dublin.

Gatfield, T. (2005). "Supervisory Styles: Overview \& Research", available at http://researchsuper.chelt.anu.edu.au/being-supervisor/supervisory-styles/overview.

Ghadirian L, Sayarifard A, Majdzadeh R, Rajabi F, Yunesian M. (2014). "Challenges for Better thesis supervision”. Medical Journal, May 10; 28:32. PMID: 25250273; PMCID: PMC4154287.

Harvey, J. (1998). "Selecting your student sample", in Evaluation Cookbook, ed., Jen Harvey, Scottish Higher Education Funding Council, Edinburg: The Learning Technology Dissemination Initiative.

Lee, A. M. (2007). "Developing effective supervisors: Concepts of research supervision", South African Journal of Higher Education, SAJHE 21 (4), available at: http://epubs.surrey.ac.uk/492/1/fulltext.pdf.

Lewis K. (2010). "Pathways toward improving teaching and learning in higher education: International context and background". New Directions for Teaching \& Learning, 2010(122):13-23. Available from: Academic Search Complete, Ipswich, MA.

McAleese, M., Bladh, A., Berger, V., Bode, C., Muehlfeit, J., Petrin, T., Schiesaro, A., Tsoukalis, L. (2013). "High Level Group on the Modernisation of Higher Education", REPORT TO THE EUROPEAN COMMISSION ON Improving the quality of teaching and learning in Europe's higher education institutions, June, available at https://www.slideshare.net/CollectifPAPERA/modernisation-higher-edjune2013.

Moon, J. (2001). “PDP Working Paper 4, Reflection in Higher Education Learning”, LTSN Generic Centre, October, 5.

Race, P. (1993). "Quality of assessment", in Never Mind the Teaching Feel the Learning, SEDA Paper, 80.

Ramsden, P. (2003). Learning to Teach in Higher Education, 2nd Ed, NY: Routhledge Falmer, ISBN-13: 978-0415303453 ISBN-10:

Sorcinelli, M. (2007). Faculty Development: The Challenge Going Forward, Fall 2007, Vol. 9, No. 4, available at http://www.aacu.org/peerreview/pr-fa07/pr-fa07_FacDev.cfm.

Supervision.ukcge.ac.uk "The Good Supervisory Practice Framework", available at https://supervision.ukcge.ac.uk/good-supervisory-practice-framework/

Strauss, A., \& Corbin, J. (1998). Basics of qualitative research: Techniques and procedures for developing grounded theory. Thousand Oaks, CA: Sage.

Visser- Wijnveen, G.J., Jan H. Van Driel, Roeland M. Van der Rijst, Nico Verloop \& Anthonya Visser. (2010). "The ideal research- teaching nexus in the eyes of academics: building profiles", Higher Education Research \& Development,29:2,195-210, DOI:10.1080/07294360903532016

Zhao, F. (2001). "Postgraduate Research Supervision: A Process of Knowledge Management", RMIT University: Centre for Management Quality Research, Bundoora West, available at http://www.providersedge.com/docs/km_articles/Postgrad_Research_Supervision_-_A_Process_of_KM.pdf. 